\title{
8
}

\section{Lawyers as Whistleblowers: The Need for a Gatekeeper of Justice Whistleblowing Obligation/Exception}

\section{Suzanne Le Mire and Christine Parker ${ }^{1}$}

In 2006 Christopher Dale, a partner in large Australian commercial law firm Clayton Utz, leaked internal law firm documents. He believed those documents showed that his own firm had assisted its tobacco company client to commit a 'fraud on justice' ${ }^{2}$ while defending a prominent case brought by Rolah McCabe, who was suffering from terminal cancer. ${ }^{3}$ The Dale case brought the possibility of lawyer whistleblowing to

\footnotetext{
1 University of Adelaide and University of Melbourne, respectively. We are grateful to Anita Mackay for her very helpful research assistance in this project. A more detailed exposition of this argument can be found in a forthcoming article: Christine Parker, Suzanne Le Mire and Anita Mackay, 'Lawyers, Confidentiality and Whistleblowing: Lessons from the McCabe Tobacco Litigation' (2017) 40(3) Melbourne University Law Review 999.

2 Dale used the term 'miscarriage of justice' and stated that he was motivated by the belief that 'there may have been a fraud committed on the Supreme Court of Victoria and that a full investigation was required': quoted in William Birnbauer, 'Lawyer Revealed as Smoking Source', The Age (online), 28 January 2007. In later litigation, it was argued that his whistleblowing fell into the 'fraud on justice' exception to lawyer-client privilege: British American Tobacco Australia Services Limited $v$ Slater \& Gordon Ltd and Roxanne Joy Cowell [2009] VSC 619 [158].

3 McCabe took action against British American Tobacco for personal injury arising from her smoking of cigarettes manufactured and sold by that company and its predecessors. The facts are described in a case Dale brought against Clayton Utz; see Christopher Anthony Dale v Clayton Utz (No 2) [2013] VSC 54, [101].
} 
our front pages, but the appropriateness of Dale's leak has remained unresolved since emerging into the public sphere. More recently, another whistleblower has exposed the way Mossack Fonseca, a Panama law firm, aided aggressive tax planning. ${ }^{4}$ It is not known whether the anonymous 'Panama papers' whistleblower is a lawyer with the firm but, like Dale, he or she had access to confidential lawyer-client information and blew the whistle with the intention of exposing a series of global injustices perpetrated by lawyers helping clients abuse the legal system. ${ }^{5}$

Under professional conduct rules and conventional codes of ethics, the breach of client confidence by a lawyer is prohibited unless it falls within certain limited exceptions. These exceptions apply in situations where a client is about to commit a serious criminal offence or is in imminent danger of serious physical harm to him or herself or another person. ${ }^{6}$

In this chapter we argue that lawyers should be permitted to whistleblow where they have information about clients or other lawyers using legal services to subvert the administration of justice in circumstances where there is misconduct analogous to situations where courts or regulatory authorities would refuse to uphold client legal privilege on the basis of the crime/fraud exception. ${ }^{7}$

First, we briefly illustrate the potential significance of lawyer whistleblowing in the justice system by describing the Dale case. Second, we argue that there is a strong ethical need for lawyers to be allowed to whistleblow in order to fulfil their obligations to act as 'gatekeepers' of the justice system when they are privy to wrongdoing that is likely to harm the justice system. The lawyer's role as gatekeeper builds on the conventional view that lawyers' duties to the court, the law and the administration of justice override their duties to clients, colleagues and third parties, and that lawyers' professional reputation is based on the assumption that they

4 Luke Harding, 'Panama Papers Source Breaks Silence over "Scale of Injustices"', Saturday 7 May 2016, The Guardian (online), www.theguardian.com/news/2016/may/06/panama-papers-sourcebreaks-silence-over-scale-of-injustices.

5 Ibid.

6 See Australian Solicitors Conduct Rules 9.2.4 and 9.2.5; and Christine Parker and Adrian Evans, Inside Lawyers Ethics (Cambridge University Press, $2^{\text {nd }}$ edn, 2014) 110-30.

$7 \quad$ For examples of this exception to privilege, see Attorney-General (NT) v Kearney (1985) 158 CLR 510, 514 (Gibbs CJ); Rv Bell; Ex parte Lees (1980) 146 CLR 141, 156 (Stephen J). The iniquity rule defence to breach of confidentiality would also apply in such situations: see Kaaren Koomen, 'Breach of Confidence and the Public Interest Defence: Is it in the Public Interest? A Review of the English Public Interest Defence and the Options for Australia' (1994) 10 Queensland University of Technology Law Journal 56. 
will not assist clients to breach the law or breach their duties to the court to serve clients' or colleagues' interests. ${ }^{8}$ We go on to suggest three guiding principles for appropriate lawyer whistleblowing relating to the nature of the relationship between the lawyer and the wrongdoer, the nature of the wrongdoing itself, and the process used to disclose the wrongdoing. The chapter suggests reforms to the law to permit and encourage appropriate lawyer whistleblowing in line with these principles.

\section{The Dale Case}

It is now well known that tobacco products kill up to one half of all their users, around 6 million people per year. The harm is seriously compounded by the highly addictive nature of cigarette smoking and the fact that many users start young. ${ }^{9}$ Serious global efforts are underway to restrict the marketing and sale of cigarettes, especially to children; to avoid others being exposed to second-hand smoke; and to implement various other measures under the auspices of the World Health Organization Framework Convention on Tobacco Control, a treaty that has been signed by 180 parties representing 90 per cent of the world's population. ${ }^{10}$

Yet there is a long history of lawyers assisting tobacco companies to avoid public and legal scrutiny of their responsibility and culpability in relation to the marketing of cigarettes, their addictiveness and harm. In the 1990s, it was revealed that tobacco companies in the UK and US had, with the help of their lawyers, hidden or destroyed many relevant documents about the health effects of smoking. ${ }^{11}$ In 2006, the NSW Dust Diseases Tribunal heard evidence from Mr Gulston, former Company Secretary and inhouse solicitor for British American Tobacco Australia Services Limited (BATAS), and a whistleblower. His evidence was that as early as 1985 Australian law firm Clayton Utz was 'warehousing'12 230,000 documents

8 The paramount duty to the court is set out in the Australian Solicitors Conduct Rules, r 3. See also John C Coffee Jr, Gatekeepers: The Professions and Corporate Governance (Oxford University Press, 2006) 2; John C Coffee Jr, 'Can Lawyers Wear Blinders? Gatekeepers and Third Party Opinions' (2005) 84 Texas Law Review 59, 67-68. See ASIC v Somerville [2009] NSWSC 934 for a case where a lawyer was sanctioned for being involved in his client's strategy to avoid paying tax debts.

9 See World Health Organization, Tobacco Fact Sheet No. 339, 6 July 2015.

10 Ibid.

11 Stanton Glantz et al (eds), The Cigarette Papers (University of California Press, 1998).

12 'Warehousing' is a term describing the transfer of the custody of documents to third parties, in order to avoid the disclosure under discovery: McCabe [328]; Camille Cameron, 'Case Note. Hired Guns and Smoking Guns: McCabe v British American Tobacco Australia Ltd' (2002) 25(3) UNSW 
and claiming privilege over them, thus avoiding its exposure in any legal proceedings. ${ }^{13}$ The copies had been given to Clayton Utz ostensibly for legal advice and the originals at BATAS destroyed. ${ }^{14}$

The McCabe case brought the ethics of tobacco company litigation tactics to a head in Australia. Rolah McCabe sued BATAS for her terminal lung cancer on the basis that she had become addicted to cigarettes as a young teenager. ${ }^{15}$ Documentary evidence showing what the tobacco company knew about the harm of its products, and how they were marketed, was clearly critical to the case. Yet few internal documents were uncovered in the usual processes of discovery because of their destruction or 'warehousing'. In 2002 Justice Eames struck out BATAS's defence on the basis that the tobacco company had 'followed a strategy designed to deny to any litigant access to documents to which the litigant would have been entitled and which would be of importance to the outcome of such proceedings'. ${ }^{16}$

Some eight months later the Victorian Court of Appeal reversed a number of Eames J's findings, restored the defence's pleadings and remitted the case for trial. ${ }^{17}$ Rolah McCabe died before the appeal decision was handed down and the full case was never heard.

The litigation tactics of BATAS and its lawyers were controversial, and were the subject of internal review by Clayton Utz and investigations by the Australian Competition and Consumer Commission, legal profession regulators and the Victorian Department of Public Prosecutions. ${ }^{18} \mathrm{New}$ legislation that criminalised the destruction of material relevant to litigation was also created in direct response to the case. ${ }^{19}$

Christopher Dale had been involved in an internal Clayton Utz review of the lawyers' conduct in the case. He believed that this review had shown that senior Clayton Utz lawyers had assisted BATAS in misleading

Law Journal 768, 784.

13 Re Mowbray: Brambles Australia Ltd v British American Tobacco Australia Services Ltd [2006] NSWDDT 15, [19]. See also, Cameron, above n 12, 781-83.

14 Susannah Moran, 'Cloaks of Privilege and Smoking Guns', The Australian Financial Review (Sydney) 19 May 2006, 57.

15 McCabe v British American Tobacco Australia Services Limited [2002] VSC 73, [7] ('McCabe').

16 McCabe [13].

17 British American Tobacco Australia Services Limited v Cowell [2002] VSCA 197, [191].

18 See Parker and Evans, Inside Lawyers Ethics, above n 6, 119-20.

19 Crimes (Document Destruction) Act 2006 (Vic); Evidence (Document Unavailability) Act 2006 (Vic). See Suzanne Le Mire, 'Document Destruction and Corporate Culture: A Victorian Initiative' (2006) 19 Australian Journal of Corporate Law 304, 308. 
the court and perverting the course of justice by destroying scientific documents that would have been relevant to litigation, hiding the extent and purpose of the destruction, and avoiding discovery of certain documents without adequate grounds. ${ }^{20}$ In late 2006, after his partnership had been terminated by the firm, Mr Dale leaked documents from the review to the McCabe family's lawyer, Peter Gordon, and through him to William Birnbauer, a journalist. ${ }^{21}$ Birnbauer published a series of newspaper articles in The Sunday Age alleging that the internal review had found evidence of lawyer misconduct. ${ }^{22}$

BATAS claimed confidentiality over the leaked documents and initiated a number of legal actions to prevent their further use. ${ }^{23}$ Dale was subjected to considerable pressure: Clayton Utz made a disciplinary complaint about $\operatorname{him}^{24}$ and BATAS sued under the general law of confidentiality. ${ }^{25}$ Despite these events, there has been no legal decision as to the appropriateness or otherwise of Dale's leak. ${ }^{26}$

20 Dale v Clayton Utz [93]-[95].

21 Ibid. [110].

22 William Birnbauer, 'Cheated by the Law. Exclusive - Exposed: Dirty Tricks Behind Top Lawyers' Plot to Deny Justice to Cancer Victims' and 'Justice Denied: How Lawyers Set Out to Defeat a Dying Woman', The Age (online), 29 October 2006; William Birnbauer, 'Lawyer Revealed as Smoking Source', The Age (online), 28 January 2007.

23 See $\mathrm{n} 24$ below.

24 Reportedly Clayton Utz made a complaint about breach of confidence to the professional disciplinary authority, although no outcome has been reported. See William Birnbauer, 'Thrust, Parry as Law Firm Slams Ex-partner', The Age (Victoria), 4 February 2007.

25 Between November 2006 and March 2007 two British American Tobacco companies in Australia sought restraining orders and injunctions against further use of the leaked material against Fairfax Publications, Slater and Gordon and Peter Gordon (the McCabe lawyers), Mrs Cowell (McCabe's executor) and Christopher Dale. These proceedings all settled with a number of restraining orders made by consent. Mrs Cowell was (reportedly) the last to settle in March 2011: see Richard Ackland, 'McCabe Litigation Took 10 Years in Two States', Justinian, 2 April 2011. See British American Tobacco Australia Ltd v Peter Gordon [2009] VSC 619; British American Tobacco Australia Services Ltd v John Fairfax Publications [2006] NSWSC 1197; British American Tobacco Australia Services Ltd $v$ John Fairfax Publications [2006] NSWSC 1175; British American Tobacco Australia Ltd v Fairfax [2006] NSWSC 1328; British American Tobacco Australia Ltd v Peter Gordon [2006] NSWSC 1473; British American Tobacco Australia Ltdv Peter Gordon [2007] NSWSC 109; British American Tobacco Australia Ltd v Peter Gordon [2007] NSWSC 230; British American Tobacco Australia Ltd v Peter Gordon [2007] NSWSC 292; McCabe v British American Tobacco Australia Services Ltd [2007] VSC 216; Cowell v British American Tobacco Australia Services Ltd [2007] VSCA 301; British American Tobacco Australia Ltd v Peter Gordon [2009] VSC 77; British American Tobacco Australia Ltd v Peter Gordon [2009] VSC 619.

26 The possibility that Dale's leak might be justified under rules of professional conduct or general laws of confidentiality was considered by the Victorian Supreme Court in interlocutory proceedings concerning an action brought by BATAS against Mrs Cowell (McCabe's executor) to restrain her from further disclosing the internal Clayton Utz documents Dale had leaked: ibid. The case was settled before any final authoritative determination of the issues was made. See above n 25 . 
While the work of lawyers can ensure 'law is still the most powerful instrument for creating and maintaining a world that is free, rational and just ${ }^{\prime}{ }^{27}$ it can also have a dark side. Global tobacco companies, with the help of their lawyers, continue their fight against tobacco control measures such as bans on advertising and plain packaging. Indeed, a recent decision by the Permanent Court of Arbitration found Philip Morris Asia's challenge to Australia's plain packaging laws to be an 'abuse of rights', essentially because it amounted to impermissible forum shopping. ${ }^{28}$ Other revelations, such as the Panama Papers leak, show that there is also a broader need to examine, debate and change the way in which lawyers work with powerful and rich clients to avoid legal scrutiny, undermine the purposes of law and regulation and thus inhibit justice.

\section{Whistleblowing}

Lawyers have explicit duties to the law, the court and the administration of justice, which are considered to be paramount over duties to clients, colleagues and the firm. ${ }^{29}$ As John Coffee Jr explains in his influential book on professionals as gatekeepers, lawyers and other professionals lend their corporate clients their 'reputational capital' and thus encourage investors, the market, other parties and indeed courts to rely on the clients' disclosures and assurances in a way that they might not if the lawyer was not involved. ${ }^{30}$ It follows that the market, the justice system, and all the parties who take part in them, rely on lawyers to act as gatekeepers and not use their reputation to assist clients who act dishonestly or illegally. Moreover it is in lawyers' own interests, as individuals and as a whole profession, to preserve their own reputation for ensuring duties to the court, the law and the administration of justice are upheld. It is therefore well established that a lawyer should be neither an instigator of, nor a party to, any breach of the law, duty to the court or abuse of justice

27 Sir Daryl Dawson, 'Legal Services Market' (1996) 5 Journal of Judicial Administration 147, 153.

28 Philip Morris Asia v Australia PCA Case no. 2012-12, Award on Jurisdiction and Admissibility,

17 December 2015.

29 Australian Solicitors' Conduct Rules, r 3.

30 John C Coffee Jr, Gatekeepers: The Professions and Corporate Governance (Oxford University Press, 2006) 2. 
by his or her clients or colleagues, and that they should act as gatekeeper at least in the sense of actively advising clients and colleagues against such breaches. ${ }^{31}$

We suggest that this 'gatekeeper of justice' role should extend to justify lawyer whistleblowing in certain circumstances (outlined in the sections below). The literature on gatekeeping generally stops short of advocating whistleblowing. Yet the gatekeeper of justice obligation is meaningless without the possibility of whistleblowing. Without that the lawyer gatekeeper is constrained to persuasion or withdrawal of services, neither of which may be effective. In effect these actions may simply defer the problem, and even render it less likely that it will be resolved in a satisfactory way. As Waters suggests, '[a]ll a silent withdrawal does is pass the problem along to another securities lawyer, possibly one who is not as concerned with ethics and professional responsibility. ${ }^{32}$

Currently lawyer whistleblowing is strongly discouraged by lawyers' confidentiality obligations. These are enshrined in the professional conduct rules enforced by the disciplinary system, implied into the terms of every lawyer-client contract, and enforceable under equitable principles of confidentiality. ${ }^{33}$ Client legal privilege, which protects lawyerclient confidentiality from enforced disclosure by courts and various enforcement authorities, has been recognised as a fundamental common law principle. ${ }^{34}$ This privilege covers information communicated from the client to the lawyer for the purposes of legal advice, and information communicated to the lawyer by third party experts for the purposes of preparation for litigation. There are even obligations of confidentiality, akin to the privilege, owed to opposing parties for material disclosed for the purposes of litigation, and equity can enforce confidentiality in any situation where information was communicated confidentially with

31 See, for example, 'Law Society of NSW v Dennis' (1981) 7 Family Law Review 417; ACCC v Real Estate Institute of Western Australia Inc [1999] FCA 18. See also Gino Dal Pont, Lawyers' Professional Responsibility (Thomson Reuters, $5^{\text {th }}$ edn, 2012) 615 (citations omitted): 'Lawyers must not engage in conduct that is dishonest, illegal, unprofessional, that may otherwise bring the profession into disrepute or that is prejudicial to the administration of justice. Lawyers must not therefore seek to advance their client's causes by unfair or dishonest means.'

32 David Waters, 'The Wisdom of Whistleblowing: The Sarbanes-Oxley Act of 2002 and the

"Noisy Withdrawal" Provision' (2010) 34 Journal of the Legal Profession 411, 423.

33 See Parker and Evans, Inside Lawyers' Ethics, above n 6, 110-13.

34 Bakerv Campbell (1983) 153 CLR 52. 
an expectation that confidentiality would be maintained. ${ }^{35}$ The justice system would not operate effectively if parties could not freely disclose information in litigation without the understanding that it will not be used for purposes other than the resolution of the dispute. ${ }^{36}$

If lawyer whistleblowing were over-encouraged, clients might lose faith in lawyer confidentiality, undermining frankness between lawyer and client and thus detracting from the administration of justice. However, the justice system is not just if lawyers see wrongdoing by clients or colleagues that amounts to a fraud on justice, are unable to prevent it via confidential advice, and have only the option of silent withdrawal or resignation in response. We argue that it is crucial to the administration of justice that professional conduct regulation sets out clear guidance and protection for appropriate whistleblowing by lawyers. This is only likely to be necessary and appropriate in certain circumstances, and there are three elements that must be considered:

- the relationship between the lawyer whistleblower and the wrongdoer - whistleblowing protection is necessary for some relationships more than others;

- only certain types of wrongdoing are serious enough to be disclosed; and

- a lawyer whistleblower faced with misconduct must use an appropriate process to seek to prevent the wrongdoing before blowing the whistle and to blow the whistle as quietly as possible consistent with effectively addressing the wrongdoing.

The remainder of the chapter discusses these three elements.

\section{A. Relationship}

The potential for lawyers to whistleblow and their vulnerability to reprisals will vary depending on the relationship between the lawyer and the wrongdoer. We canvas four possible situations below. We suggest

35 Matthew Groves, 'The Implied Undertaking Restricting the Use of Material Obtained during Legal Proceedings' (2003) 23(3) Australian Bar Review 314-44.

36 See discussion of the implied undertaking in British American Tobacco Australia Services Ltd $v$ Cowell (as representing the estate of Rolah Ann McCabe, deceased) [2003] VSCA 43, [19-20]. 
that lawyers in each of the situations should be permitted to blow the whistle and given protection from retaliation if they do so via changes to professional conduct rules and legal profession regulation.

Lawyers in an internal or employment relationship with the wrongdoer are most likely to hold information 'worthy of disclosure' (the criteria for what should be disclosed are addressed in the next subsection). ${ }^{37}$ External lawyers directly briefed by the wrongdoing organisation may also identify wrongdoing, although in such a case the client can tailor information to obscure it. Lawyers in both these situations may be able to prevent wrongdoing through their advice to the client. However, if that advice is ignored and the client persists with the wrongdoing, then the lawyer should whistleblow. In such a situation, the strength of the duty of confidentiality and loyalty to the client, and the vulnerability to retaliation through loss of employment, disciplinary complaint or lawsuit, is currently high. Professional conduct rules should set out when whistleblowing should be allowed and provide protection from retaliation similar to that provided to public sector employees under the Public Interest Disclosure Act.

Lawyers may also discover wrongdoing involving their colleagues in the firm and the clients of their colleagues. All partners in a firm have an obligation to ensure ethical conduct in the firm. ${ }^{38}$ But there are significant disincentives for whistleblowing within a law firm if and when counselling and persuasion fail. If one lawyer in a firm owes obligations of confidentiality to a client or in relation to information communicated by a third party, then all lawyers in the firm will be bound. Thus, in the Dale case, even though Dale did not himself act for the tobacco company, as a partner in the firm he owed obligations of confidentiality to all his firm's clients as if he was their own lawyer. He would also have owed obligations of confidentiality in equity and contract to his fellow partners in his firm about internal operations of the firm. This situation should also be covered by whistleblowing exceptions to confidentiality and protection of the lawyer whistleblower.

Lawyers might discover the wrongdoing of those on the other side in a transaction or in litigation. For these lawyers, their duty and vulnerability to retaliation and discipline will depend in part on the attitude of their

37 Paul Latimer and A J Brown, 'Whistleblower Laws: International Best Practice' (2008) 31 University of New South Wales Law Journal 766, 775.

38 This flows from the vicarious liability of partners: for example, Partnership Act 1891 (SA) s 10. See also, for example, obligations to supervise, Australian Solicitors' Conduct Rules (ACSR) r 37. 
own client to the disclosure. So, for example, clients may retaliate if the disclosure is not in their interests by lodging a complaint (which may or may not be successful), or curtailing work. A second layer of confidentiality may exist if the lawyer has come across the information in a context where there has been an undertaking to preserve confidence, such as in a due diligence or discovery process. ${ }^{39}$

The final relationship within which a lawyer could be a whistleblower concerns those lawyers who discover wrongdoing through their personal or professional networks. The lawyer's power to intervene is less obvious in this context, and the whistleblowing might simply take the form of a disciplinary complaint about the wrongdoer.

It is plausible that reforms to support whistleblowing explicitly would assist those considering their response to wrongdoing. So, for example, changes to the professional conduct rules and other legislative whistleblower protections (including, for example, Pt 9.4AAA of the Corporations Act and the Commonwealth Public Interest Disclosure Act) could assist in building a culture of permission for appropriate lawyer whistleblowing, while also addressing the possibility of reprisals.

\section{B. Wrongdoing}

We suggest that where misconduct is analogous to conduct that would fall within the crime/fraud exception to lawyer client privilege, then gatekeeper of justice obligations are triggered and external whistleblowing may be permitted if other measures to address the misconduct fail (as discussed in the next section). The crime/fraud exception to privilege covers information about the commission of a crime, fraud or civil offence, ${ }^{40}$ and extends to 'communications made with the intention of frustrating the processes of law, and which may be described as a "fraud on justice". ${ }^{41}$ The courts already recognise that the privilege should not apply in such circumstances because clients should not be able to rely on lawyer confidentiality where that would conflict with the lawyers' role as an officer of the court. The 'iniquity rule' defence to breach of confidence

39 See, for example, The Solicitor-General v Miss Alice [2007] 2 NZLR 783.

$40 \quad R v$ Cox \& Railton (1884) 10 QBD 153 [158].

41 Attorney-General (NT) v Kearney (1985) 158 CLR 510, 514 (Gibbs CJ); $R v$ Bell; Ex parte Lees (1980) 146 CLR 141, 156 (Stephen J); British American Tobacco Australia Limited v Peter Gordon [2009] VSC 619 [158]. 
at equity would also apply in such situations. ${ }^{42}$ Professional conduct rules should also be changed to recognise that whistleblowing can be appropriate where the crime/fraud exception would apply (provided an appropriate process is followed).

Examples of the kind of wrongdoing that could justify whistleblowing on the part of the lawyer under this exception include situations where the courts or other regulatory authorities have been misled or deceived by either the lawyer's own client or a lawyer or client on the other side, or indeed anyone else. This is the situation alleged by Dale. Dale stated that he was motivated by the belief that 'there may have been a fraud committed on the Supreme Court of Victoria and that a full investigation was required. ${ }^{43}$ His leaks were aimed at providing further evidence that the client and the law firm acted in violation of the applicable norms by concealing evidence of the intentionally manipulative or negligent marketing of a product known to be harmful, and subverting the judicial process to avoid scrutiny and liability for its own harmful conduct.

Another example would be the Australian Wheat Board's subversion of the UN's 'Oil for Food' program to illegally channel funds to Saddam Hussein's regime. ${ }^{44}$ In such a situation the lawyer would have a clear duty not to counsel or assist in illegal conduct. ${ }^{45}$ However, should the client persist with the wrongdoing, the pressure on the lawyer to conceal the wrongdoing is likely to be high. Moreover the client may embroil the lawyer in its illegal purpose by expecting the lawyer to defend and even further the client's purpose. This type of wrongdoing furthers the organisation's purpose, yet falls within the crime/fraud exception, and

42 The iniquity rule defence to breach of confidence at general law covers 'crimes, frauds and misdeeds' including civil wrongs: Initial Services v Putterill [1968] 1 QB 396; see also Kaaren Koomen, 'Breach of Confidence and the Public Interest Defence: Is it in the Public Interest? A Review of the English Public Interest Defence and the Options for Australia' (1994) 10 Queensland University of Technology Law Journal 56, 58.

43 William Birnbauer, 'Lawyer Revealed as Smoking Source', The Sunday Age 28 January 2007. Quoted in Dale v Clayton Utz [101]. Dale repeated the substance of this account in his evidence to the court in Dale $v$ Clayton Utz: see [101].

44 Caroline Overington, Kickback: Inside the Australian Wheat Board Scandal (Allen and Unwin, 2007).

45 See, for example, 'Law Society of NSW v Dennis' (1981) 7 Family Law Review 417; ACCC v Real Estate Institute of Western Australia Inc [1999] FCA 18. See also Gino Dal Pont, Lawyers' Professional Responsibility (Thomson Reuters, $5^{\text {th }}$ edn, 2012) 615 (citations omitted): 'Lawyers must not engage in conduct that is dishonest, illegal, unprofessional, that may otherwise bring the profession into disrepute or that is prejudicial to the administration of justice. Lawyers must not therefore seek to advance their client's causes by unfair or dishonest means.' 
thus it is desirable to make the conduct rules clear about when and how lawyers can whistleblow externally in such a situation and provide them with protection from retaliation if they do so.

\section{The process}

Whistleblowing is ethically problematic because it breaches shared understandings of loyalty and confidentiality within a relationship or organisation. ${ }^{46}$ It is, therefore, important that lawyer whistleblowers leak confidential information only when it is ethically justified to do so and do not unnecessarily breach other ethical obligations in the process. ${ }^{47}$ In order to encourage appropriate use of a whistleblowing exception, the conduct rules should set out the circumstances when whistleblowing is permissible and the process that should be followed.

First, the conduct rules should require lawyer whistleblowers to use judgment and ensure they are accurate in their assessment of any wrongdoing. That is, they should verify that they have accurate and sufficient evidence to at least prompt a further investigation by a regulatory authority before whistleblowing.

Second, the rules should ensure the breach of loyalty is minimised by directing lawyer whistleblowers to explore appropriate alternative options for preventing wrongdoing (such as strong advice and persuasion) before sounding the alarm. Other reasonable options for addressing the wrongdoing should be exhausted before whistleblowing. This also means that any disclosure should be as narrow as possible and directed to the appropriate party who can rectify or prevent the wrong - usually, first, an authoritative figure within the firm or company, and then a regulatory authority or court. Public disclosure, such as via the media in the Dale case, should generally be a last resort as it carries with it a complete loss of control over the information in ways that do not necessarily occur when information is disclosed to regulators or courts.

Third, the rules should encourage lawyer whistleblowers to disclose sufficient information but only that which is necessary to address the wrongdoing. They should not, for example, disclose extraneous personal

46 Sissela Bok, Secrets: On the Ethics of Concealment and Revelation (Vintage Books, 1989) 120.

47 Based on Bok, ibid, 219ff. 
matters or hide what evidence they have. Rather, the whistleblowing should put matters of significance to an appropriate forum for investigation and accountability.

Changes such as these to the professional conduct rules, coupled with education by legal profession regulators and appropriate protections for lawyer whistleblowers in legislation, would provide guidance to potential whistleblowers faced with difficult choices. Once appropriate changes are made to the professional conduct rules, lawyers could draw on existing ethical guidance hotlines for advice about the appropriateness and process for whistleblowing, and should be protected from disciplinary action if they seek and follow such advice. Ultimately this could enhance the possibility that wrongdoing that impacts the justice system would be confidentially investigated and, where appropriate, brought into public discussion and accountability.

\section{Concluding Remarks}

Lawyer whistleblowing has the potential to address specific occasions of harm to the administration of justice. It has barely, however, been addressed by professional conduct rules and professional regulators. Our chapter suggests how to begin to address this issue in the legal profession. The changes we have proposed could assist practitioners as well as provide a welcome demonstration of the profession's commitment to justice. 
This text is taken from New Directions for Law in Australia: Essays in Contemporary Law Reform, edited by Ron Levy, Molly O’Brien, Simon Rice, Pauline Ridge and Margaret Thornton, published 2017 by ANU Press, The Australian National University, Canberra, Australia. 